\title{
Over-expression and characterization of NS3 and NS5A of Hepatitis C virus genotype $3 a$
}

\author{
Muhammad Ikram Anwar ${ }^{1}$, Mazhar lqbal ${ }^{1 *}$, Mohammad S Yousef $^{2,3}$ and Moazur Rahman ${ }^{{ }^{*}}$
}

\begin{abstract}
Background: Hepatitis C virus (HCV) is a common and leading cause for liver cirrhosis and hepatocellular carcinoma. Current therapies to treat HCV infection are shown to be partially effective and poorly tolerated. Therefore, ample efforts are underway to rationally design therapies targeting the HCV non-structural proteins. Most of the work carried out in this direction has been focusing mainly on HCV genotype 1. Two direct-acting antiviral agents (DAAs) Telaprevir and Boceprevir are being used against genotype 1a infection in combination therapy with interferon and ribavirin. Unfortunately these DAAs are not effective against genotype 3a. Considering the wide spread infection by HCV genotype $3 a$ in developing countries especially South Asia, we have focused on the recombinant production of antiviral drug targets NS3 and NS5A from HCV genotype 3a. These protein targets are to be used for screening of inhibitors.

Results: High-level expression of NS3 and NS5A was achieved at $25^{\circ} \mathrm{C}$, using $\sim 1$ and $0.5 \mathrm{mM}$ Isopropyl $\beta$-D-1-thiogalactopyranoside (IPTG), respectively. Yields of the purified NS3 and NS5A were 4 and $1 \mathrm{mg}$ per liter culture volume, respectively. Although similar amounts of purified NS3 were obtained at 25 and $14^{\circ} \mathrm{C}$, specificity constant $\left(K_{\text {cat }} / K_{\mathrm{m}}\right)$ was somewhat higher at expression temperature of $25^{\circ} \mathrm{C}$. Circular dichroism (CD) and Fourier-transform infrared (FT-IR) spectroscopy revealed that both NS3 and NS5A contain a mixture of alpha-helix and beta-sheet secondary structures. For NS3 protein, percentages of secondary structures were similar to the values predicted from homology modeling.

Conclusions: NS3 and NS5A were over-expressed and using Nickel-affinity method both proteins were purified to 95\% purity. Yield of the purified NS3 obtained is four fold higher than previous reports. CD spectroscopy revealed that difference in activity of NS3 expressed at various temperatures is not related to changes in global structural features of the protein. Moreover, CD and FT-IR analysis showed that NS3 and NS5A contain both alpha-helical and beta-sheet structures and for NS5A, the proportion is almost equal. The production of NS3 and NS5A in milligram quantities will allow their characterization by biophysical and biochemical means that will help in designing new strategies to fight against HCV infection.
\end{abstract}

Keywords: HCV, NS3, NS5A, Genotype 3a, Protease, Helicase, Viral replication, Protein expression, CD spectroscopy, FT-IR

\section{Background}

Hepatitis C Virus (HCV) was first identified in 1989 [1], however, research was initially delayed due to the difficulty to culture the virus efficiently in vitro [2]. $\mathrm{HCV}$ is a major public health threat worldwide that could lead to fibrosis, cirrhosis, hepatocellular carcinoma,

\footnotetext{
* Correspondence: hamzamgondal@gmail.com; moazur@yahoo.com 'Drug Discovery and Structural Biology group, Health Biotechnology Division, National Institute for Biotechnology and Genetic Engineering (NIBGE), Faisalabad, Pakistan

Full list of author information is available at the end of the article
}

liver failure and death of the infected person [3]. According to an estimate of World Health Organization, around 170 million people are infected with $\mathrm{HCV}$, with an additional 3-4 million infected every year [4]. The risk of the prevalence of this disease is decreased with the advent of new blood screening tests. Yet, in developing countries, wide transmission still occur mainly by parenteral exposure to contaminated blood or blood products or by the illicit use of injectable drugs [5].

$\mathrm{HCV}$ belongs to genus hepacivirus of family Flaviviridae and is an enveloped positive stranded RNA virus [6]. It

\section{Biomed Central}


has a genome size of $9.6 \mathrm{~kb}$ and encodes a single polyprotein of 3000 amino acids which is further cleaved into 10 proteins by host signal peptidases and viral proteases $[7,8]$. Coding sequences for first 3 structural proteins reside in the 5' region of $\mathrm{HCV}$ genome including the core (C), and two envelope glycoproteins (E1 and E2). The structural proteins play a major role in the encapsulation of the virus. C, E1 and E2 genes are followed by p7 gene whose product is considered to work as an ion channel and its maturation is catalyzed by endogenous peptidases. Coding regions of six non-structural proteins (NS2, NS3, NS4A, NS4B, NS5A and NS5B) are present at 3' end of $\mathrm{HCV}$ genome. Non-structural proteins are mainly involved in process of replication and maturation of HCV [9].

In spite of the intensive research on $\mathrm{HCV}$, it continues to pose a major threat to the developing world. The only treatment available for $\mathrm{HCV}$ is pegylated interferon alone or in combination with ribavirin for 24 to 48 weeks based on the genotype of virus. Response of genotype 1 to current treatment is 42 to $46 \%$ whereas genotypes $2 /$ 3 responds to 76 to $80 \%$ [10]. This antiviral therapy is expensive, has considerable side effects and in some cases is not effective beyond the period of treatment. A number of DAAs are in clinical phase 1,2 and 3 trials that are designed against specific protein targets (NS3, NS5A and NS5B) which are essential to the life cycle of the virus [11-13]. Two DAAs Telaprevir and Boceprevir have been approved by FDA in 2011. These DAAs are used in combination therapy with interferon and ribavirin to combat infections caused by HCV genotype 1a [14]. NS3 and NS5B are considered to be the main targets of this regime because they can be directly used for inhibitors screening due to their enzymatic properties [15]. NS3 consists of 631 amino acids (aa), out of which $\mathrm{N}$-terminal 180 aa form a protease domain while remaining constitutes helicase/ATPase part of the protein. The protease domain plays an important role in the processing of $\mathrm{HCV}$ polyprotein using the NS4A as a cofactor [16]. NS4A not only plays an important role in the activation of NS3 protease, it also anchors NS3 to membrane of endoplasmic reticulum during process of replication [17]. Helicase domain of NS3 activates the separation of double stranded RNA using ATP as an energy source [18]. Moreover, NS3 also interferes the host immune system by targeting the host proteins such as TRIF and MAVS that act as signaling adapter for toll like receptor 3 and mitochondrial antiviral signaling protein, respectively [16]. Although Protease and helicase domains of NS3 can work independently, cofactor NS4A is required for efficient functioning of NS3 protease [19].

NS5A performs critical role in the virus persistence and pathogenesis. Its interaction with a large number of host and viral proteins during replication and assembly of virus, makes this protein an important antiviral drug target $[20,21]$. NS5A also has significant role in the process of lipid accumulation that finally leads to steatosis $[22,23]$. Work on the discovery of NS5A' inhibitors is continuing and so far only one inhibitor "Daclatasvir" is available that is in phase 3 clinical trials [13,24]. Daclatasvir is effective for treatment of infection caused by HCV genotype 1a. NS5A consists of 3 domains; domain I and domain II are essential for viral replication whereas domain III plays a key role in virion assembly $[25,26]$. The crystal structure of domain 1 has been solved, suggesting that NS5A forms a dimer that contains a groove for binding RNA at the interface between the monomers [27].

The prevalence of HCV in Pakistan/South Asia is on the rise, currently at approximately $10 \%$ [28]. The most prevalent genotype in this region is 3a [29]. Inhibitors such as Telaprevir, Boceprevir and TMC435 targeting NS3 are only effective against HCV genotype 1. MK-5172, another inhibitor of NS3, which is supposed to be effective against all genotypes, is still in clinical trials [30]. Research is progressing to exploit the potential of NS5A as an antiviral target [31].

First step towards designing effective inhibitors is to obtain sufficient quantities of the target protein. Such quantities will enable extensive functional and structural analyses required for the rational design of inhibitors. To our knowledge there is no systematic study has been performed to over-express and purify NS3 and NS5A of HCV genotype 3a. Considering the importance of NS3 and NS5A as antiviral drug targets, we have successfully devised over-expression and purification methods to produce the indicated proteins in quantities sufficient for functional and structural studies with and without inhibitors. In addition, we have functionally and structurally characterized HCV NS3 and NS5A proteins from genotype $3 a$.

\section{Results and discussion}

Infections caused by HCV pose major threats to human health. Recently launched 'NS3' inhibitors (Telaprevir, Boceprevir and TMC435) for treatment of HCV genotype are found to be ineffective against HCV patients infected with genotype $3 \mathrm{a}$, which is prevalent in several developing countries [32]. This might be due to amino acid sequence variability among NS3 proteins from different genotypes (Figure 1A). In addition to NS3 as an antiviral drug target, significant efforts are now being made to exploit the potential of NS5A [33]. Compared to NS3 sequence variability, the sequence of NS5A is even more variable (30-40\%) among different HCV genotypes (Figure 1B). This fact highlights the need to synthesize and characterize these target protein from different genotypes to combat $\mathrm{HCV}$ infection worldwide [34]. As a step forward, we have isolated HCV genotype 3 strain from blood sample of a Pakistani patient that was used for synthesis of viral 

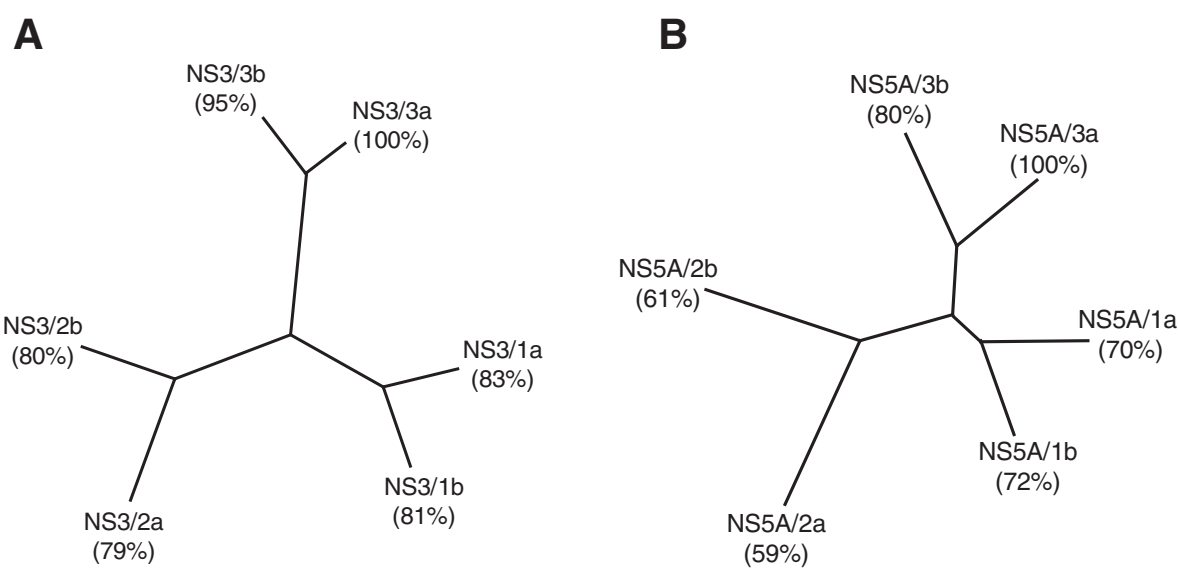

Figure 1 Percentage sequence identities between NS3 $[A]$ and NS5A [B] proteins of various genotypes of hepatitis $C$ virus. The phylogenetic trees and percent identity were derived from alignments of amino acid sequences of NS3 and NS5A proteins using the program ClustalX, version 1.83. Percent identity of NS3/3a and NS5A/3a to proteins of other genotypes is indicated. The tree was drawn using the TreeView program. [A] The phylogenetic tree includes: NS3/3a (NCBI GenBank acc. no. AFJ79449), NS3/3b (BAA08372; Amino acids 1035-1665), NS3/2a (BAB32872.1; Amino acid 1031-1661), NS3/2b (BAB08107; Amino acid 1031-1661)), NS3/1a (AAB66324; Amino acid 1027-1657), NS3/1b (BAC54896; Amino acid 1027-1657). [B] The phylogenetic tree includes: NS5A/3a (AFJ79451), NS5A/3b (BAA08372; Amino acid 1981-2432), NS5A/ 2b (AAF59945; Amino acid 1977-2442), NS5A/2a (AAF01178; Amino acid 1977-2442), NS5A/1a (AAB66324; Amino acid 1973-2420), NS5A/1b (AAC15725; Amino acid 1973-2419).

cDNA. The nucleotide sequences coding for NS3 and NS5A proteins were amplified using the isolated cDNA as a template. Nucleotide sequences of NS3 and NS5A were deposited in GenBank NCBI under accession numbers JQ676838 and JQ676840, respectively.

\section{Strategy for the generation of NS3, NS5A and NS5A-T expression constructs}

Nucleotide sequences of NS3, NS5A (Full length; nucleotides coding for 1-452 amino acids) and NS5A-T (truncated; 32-452 amino acids) along with coding sequence for $\mathrm{His}_{6}$ at the $5^{\prime}, 3^{\prime}$ and $5^{\prime}$ ends, respectively, were cloned into pET11a vector. Resultant vectors were named as pET11aHis $_{6}-\mathrm{NS} 3$, pET11a-NS5A-His 6 and pET11a-NS5A-T-His 6 and overall strategy is shown in Figure 2. The Integrity of constructs was confirmed by DNA sequencing.

\section{Expression of NS3, NS5A and NS5A-T}

Initial expression of $\mathrm{His}_{6}-\mathrm{NS} 3$, NS5A-His 6 and $\mathrm{His}_{6}-$ NS5A-T was conducted at $37^{\circ} \mathrm{C}$ using $1 \mathrm{mM}$ IPTG concentration in E. coli strain BL21(DE3) as described in Methods section. Truncated version of NS5A-T (32-452 amino acids) was also tested to evaluate the effect of $\mathrm{N}$-terminal domain of 31-amino acids (which contains an amphipathic helix that serves as a membrane anchor) on protein expression [35,36]. Significant expression levels of $\mathrm{His}_{6}-\mathrm{NS} 3$ and $\mathrm{His}_{6}-\mathrm{NS} 5 \mathrm{~A}-\mathrm{T}$ were obtained whereas NS5A-His 6 was expressed to low level as detected by Coomassie blue staining of SDS-polyacrylamide gel (data not shown). Therefore, further studies were conducted using truncated version of NS5A.
To enhance the expression level and solubility of $\mathrm{His}_{6}{ }^{-}$ NS3 and His $_{6}$-NS5A-T/HCV genotype 3a, concentration of inducer 'IPTG' was optimized [37]. Previous studies report that expression of NS3/HCV genotype $1 \mathrm{a} / 2 \mathrm{~b} / 3 \mathrm{a}$ usually obtained at $1 \mathrm{mM}$ IPTG or $0.002 \% \mathrm{~L}$-arabinose using $\mathrm{pET}$ or $\mathrm{pBAD}$ vector systems [38-40] whereas NS5A/ HCV genotype $1 \mathrm{a} / 1 \mathrm{~b}$ is produced using $0.2-1 \mathrm{mM}$ IPTG [21,41-43]. Various IPTG concentrations ranging from $0.1-1 \mathrm{mM}$ as detailed in Methods section were employed for expression in this study. For both proteins, expression yielded bands migrating at $\sim 68.3$ and $\sim 46.5 \mathrm{kDa}$ for $\mathrm{His}_{6}$-NS3 and $\mathrm{His}_{6}$-NS5A-T, respectively (Figure 3). A significant proportion of proteins expressed as soluble at all IPTG concentrations. Overall, little variation in expression of both proteins was observed at IPTG ranging from 0.1 to $1 \mathrm{mM}$. For further expression studies, 1 and $0.5 \mathrm{mM}$ IPTG concentrations were selected for $\mathrm{His}_{6}$-NS3 and $\mathrm{His}_{6}-\mathrm{NS} 5 \mathrm{~A}-\mathrm{T} / \mathrm{HCV}$ genotype $3 \mathrm{a}$.

\section{Temperature optimization and purification of NS3 and NS5A-T}

Previous studies report expression of NS3 and NS5A from different $\mathrm{HCV}$ genotypes using a range of temperatures. For example, expression of NS3/HCV genotype 1a/ $2 \mathrm{~b} / 3 \mathrm{a}$ has been achieved at $30^{\circ} \mathrm{C}$ and $22^{\circ} \mathrm{C}$ [38-40], and NS5A has been expressed at room temperature in most of studies $[21,41,43,44]$. In this study, we systematically investigated the affect of temperature $\left(32^{\circ} \mathrm{C}, 25^{\circ} \mathrm{C}\right.$ and $14^{\circ} \mathrm{C}$ ) on expression and purification yield of $\mathrm{His}_{6}-\mathrm{NS} 3$ and $\mathrm{His}_{6}-\mathrm{NS} 5 \mathrm{~A}-\mathrm{T} / \mathrm{HCV}$ genotype $3 \mathrm{a}$. Both proteins can be expressed at all tested temperatures and purified by 


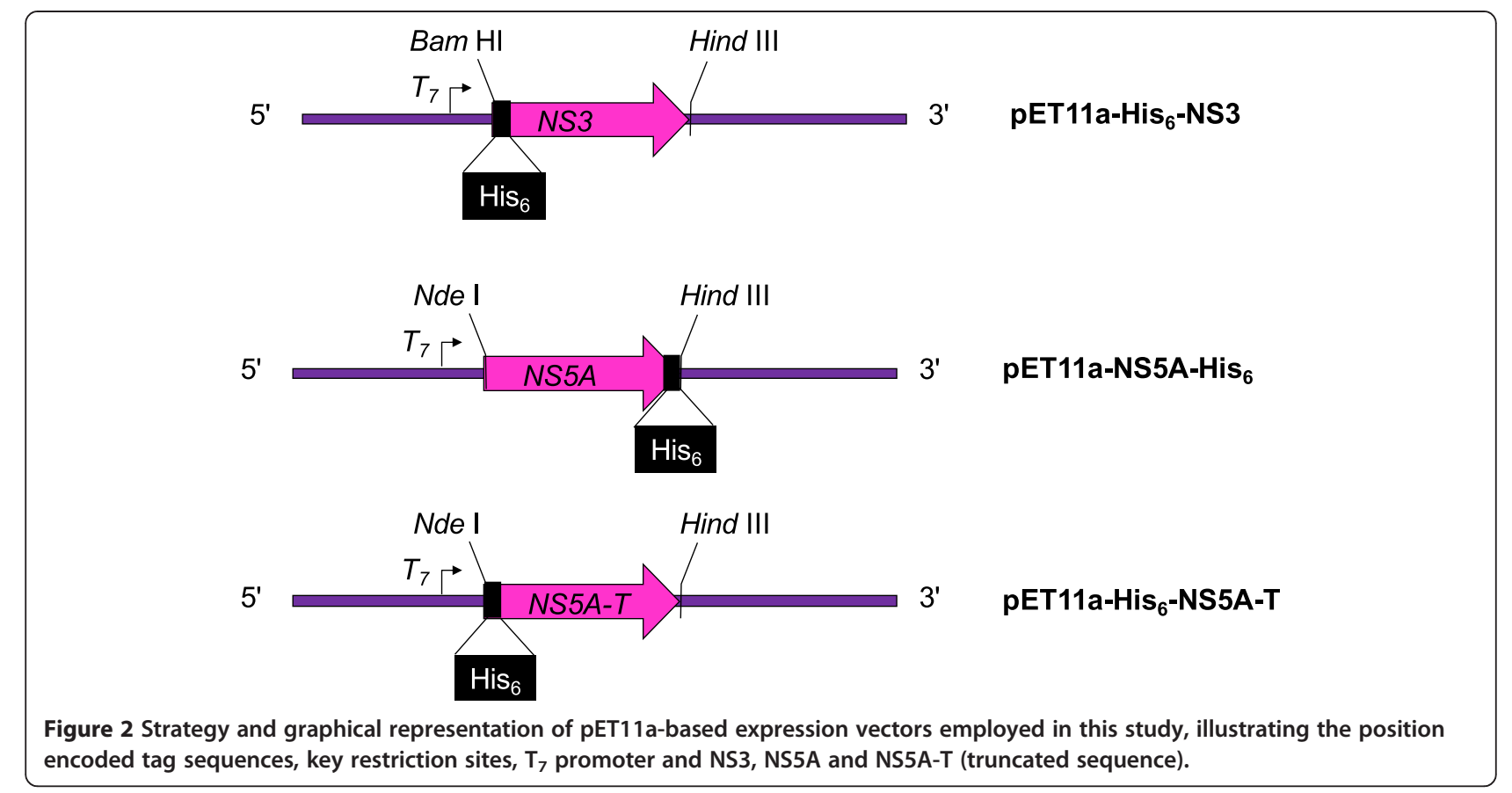

single step Ni-NTA affinity chromatography to 95\% purity as judged by Coomassie blue staining (Figure 4). $\mathrm{His}_{6}-\mathrm{NS} 5 \mathrm{~A}-\mathrm{T}$ is further polished by gel filtration to produce homogenous and mono-disperse protein (Figure 4B, lane 4). Higher purification yields 4.0 and $1.0 \mathrm{mg}$ per liter culture volume were obtained at both $25^{\circ} \mathrm{C}, 14^{\circ} \mathrm{C}$ and $25^{\circ} \mathrm{C}$ for $\mathrm{His}_{6}-\mathrm{NS} 3$ and $\mathrm{His}_{6}-\mathrm{NS} 5 \mathrm{~A}-\mathrm{T}$, respectively (Table 1). Optimized expression conditions yielded four fold purified $\mathrm{His}_{6}-\mathrm{NS} 3$ than achieved earlier [40] whereas $\mathrm{His}_{6}-\mathrm{NS} 5 \mathrm{~A}-\mathrm{T}$ yield was somewhat similar as reported in earlier studies for NS5A or NS5A-T/HCV genotype $1[41,44]$. Higher purification yield of NS3/3a might be due to its sequence variability from NS3 sequences of other genotypes (Figure 1A). Identity of purified NS3 and NS5A was confirmed by peptide mass finger printing based mass-spectrometry method. $C D$ analyses of the purified $\mathrm{His}_{6}-\mathrm{NS} 3$ and $\mathrm{His}_{6}-\mathrm{NS} 5 \mathrm{~A}-\mathrm{T}$ produced at different temperatures $\left(32^{\circ} \mathrm{C}, 25^{\circ} \mathrm{C}\right.$ and $\left.14^{\circ} \mathrm{C}\right)$ revealed that both proteins are folded polypeptides (Figure 5).

Activity measurements of NS3 produced at different temperatures

Activity of purified $\mathrm{His}_{6}-\mathrm{NS} 3$ produced at $32^{\circ} \mathrm{C}, 25^{\circ} \mathrm{C}$ and $14^{\circ} \mathrm{C}$ was measured using a FRET based assay as
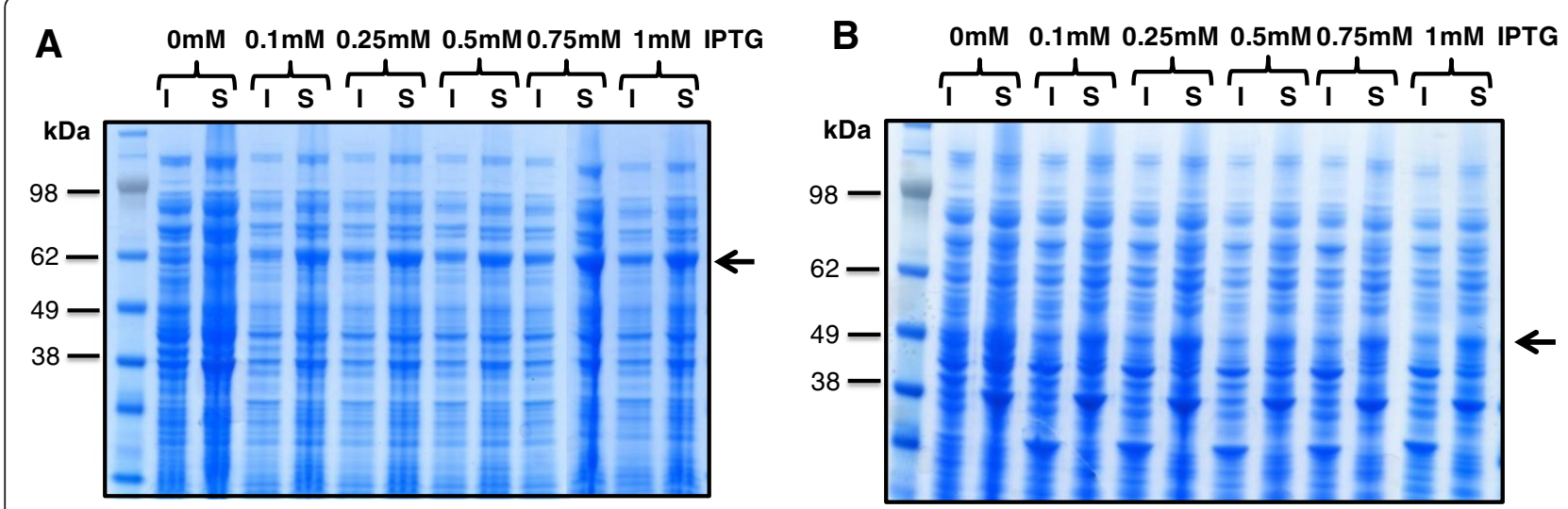

Figure 3 Expression of $\mathrm{His}_{6}-\mathrm{NS} 3$ [A] and NS5A-T-His ${ }_{6}[\mathrm{~B}]$ in E. coli strain BL21(DE3) and isopropyl- $\beta$-D-thiogalactoside (IPTG). 'I' and 'S' represent insoluble (inclusion body) and soluble fraction of lysate obtained from cultures harbouring pET11a- His $\sigma_{6}-\mathrm{NS} 3$ [A] or pET11a- NS5A-T-His 6 [B] induced with indicated concentration of IPTG. The arrows indicate the mobility of monomeric His 6 -NS3 [A] and NS5A-T-His 6 [B]. The lane on the left shows marker proteins of known molecular mass. 


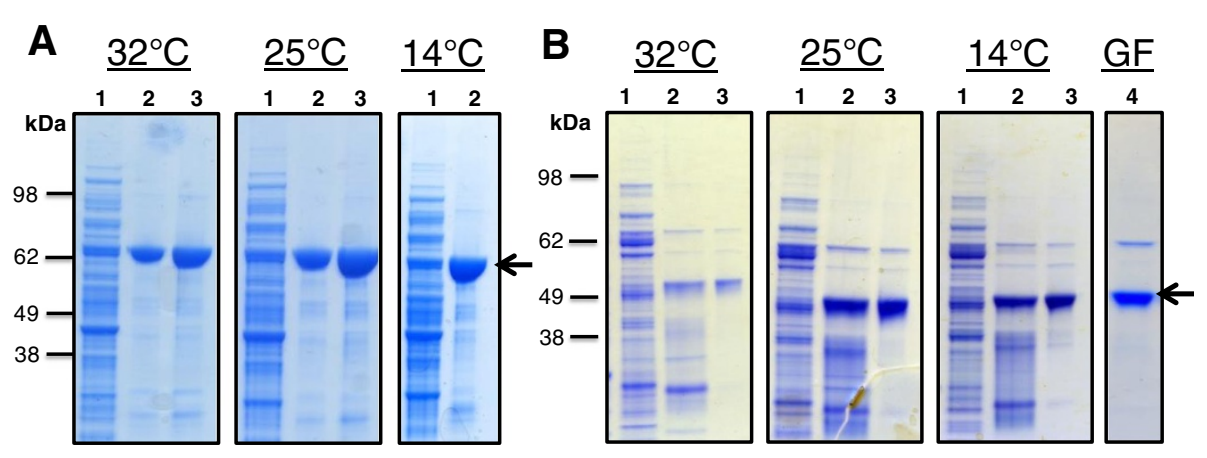

Figure 4 Optimization of expression of $\mathrm{His}_{6}-\mathrm{NS} 3[\mathrm{~A}]$ and NS5A-T-His 6 [B] in E. coli strain BL21(DE3) at various temperatures and purification by Nickel affinity chromatography following gel filtration in case NS5A-T-His 6 [B]. SDS-polyacrylamide gels stained with Commassie brilliant blue, showed wash fraction (lane 1), purified protein fractions eluted from Ni-NTA column using 250 mM imidazole (lane 2\&3) and purified fraction of NS5A-T-His 6 by gel filtration as described in Methods section. The mobilities of marker proteins of known molecular mass are shown on the left.

described in Methods section. His $_{6}$-NS3 expressed at different temperatures, exhibit similar $K_{\mathrm{m}}$ value when measured at single detergent concentration $(0.1$ or $0.4 \%$ n-Octyl- $\beta$-D-glucopyranoside; OGP) (Figure 6). Using assay buffer containing 0.1\% OGP, higher $K_{\mathrm{m}}$ value $(\sim 1.3 \mu \mathrm{M})$ for $\mathrm{His}_{6}-\mathrm{NS} 3$ was obtained than at $0.4 \%$ OGP $(\sim 0.3 \mu \mathrm{M}) . K_{\mathrm{m}}$ value in the range of $1.3 \mu \mathrm{M}$ has been determined before for NS3/HCV genotype 1a [38]. Maximum turnover number $\left(K_{\text {cat }}\right)$ and specificity constant $\left(K_{\mathrm{cat}} / K_{\mathrm{m}}\right)$ were found to be higher for the enzyme expressed at $32^{\circ} \mathrm{C}$ at both OGP concentration used in assay buffer (Table 2). However, taking into account the purification yield of $\mathrm{His}_{6}$-NS3 at various temperatures, the expression at $25^{\circ} \mathrm{C}$ seems to be the best to get the largest amount of enzyme, with catalytic efficiency sufficient for conducting assays for intensive search of inhibitors (Table 2). Relatively higher specificity constant $\left(K_{\text {cat }} / K_{\mathrm{m}}\right)$ for $\mathrm{His}_{6}$-NS3, expressed at $32^{\circ} \mathrm{C}$ might be due to local perturbation at around active site of the enzyme which could be the subject of future investigations.

Although similar $K_{\mathrm{m}}$ values were obtained for $\mathrm{His}_{6}$-NS3, expressed at various temperatures, $K_{\text {cat }} / K_{\mathrm{m}}$ constants were different to some extent. To investigate, whether these differences relate to changes in overall structural features of the protein, $\mathrm{CD}$ analysis was performed. The CD spectra of $\mathrm{His}_{6}$-NS3 proteins expressed at different temperatures are almost identical in the region between $200-240 \mathrm{~nm}$ that reflects the secondary structure propensities in

Table 1 Purification yield of NS3 and NS5A-T

\begin{tabular}{|c|c|c|c|c|}
\hline $\begin{array}{l}\text { Protein } \\
\text { Temperature }\end{array}$ & $32^{\circ} \mathrm{C}$ & $25^{\circ} \mathrm{C}$ & $14^{\circ} \mathrm{C}$ & Reported \\
\hline NS3 $(\mathrm{mg} / \mathrm{L})^{1}$ & 2.5 & 4.0 & 4.0 & $0.3[38], 0.92[40], 0.45[39]$ \\
\hline NS5A-T (mg/L) ${ }^{1}$ & 0.32 & 1.0 & 0.8 & $1.0[41]$ \\
\hline
\end{tabular}

${ }^{1}$ The yield of purified proteins were measured $\mathrm{mg} /$ liter of culture (expression medium). proteins (Figure 5A) [45]. Thus, it is likely that the overall structural features in $\mathrm{His}_{6}$ - $\mathrm{NS} 3$ expressed at various temperatures remain intact and the cleavage efficiency of the protein does not relate to any global structural changes.

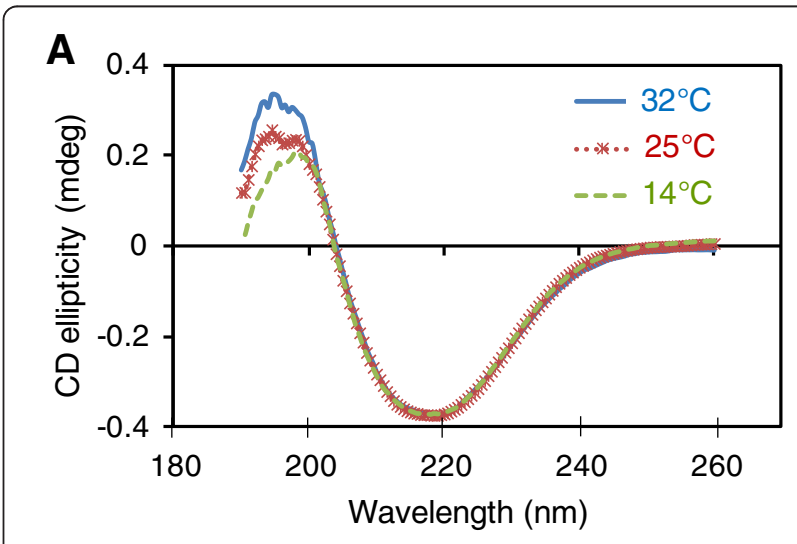

B

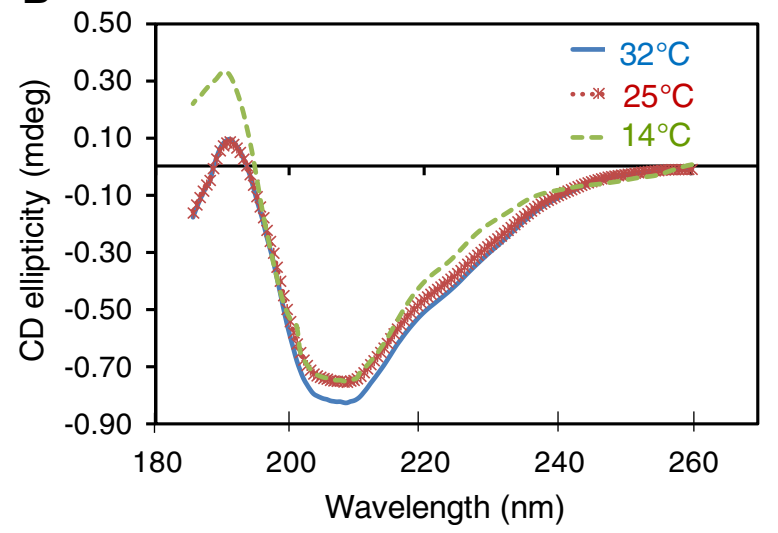

Figure 5 Characterization of $\mathrm{His}_{6}-\mathrm{NS} 3[\mathrm{~A}]$ and NS5A-T-His 6 [B] over-expressed at $32^{\circ} \mathrm{C}, 25^{\circ} \mathrm{C}$ and $14^{\circ} \mathrm{C}$ by circular dichroism spectroscopy. $\mathrm{CD}$ experiments were performed as described in Methods. 

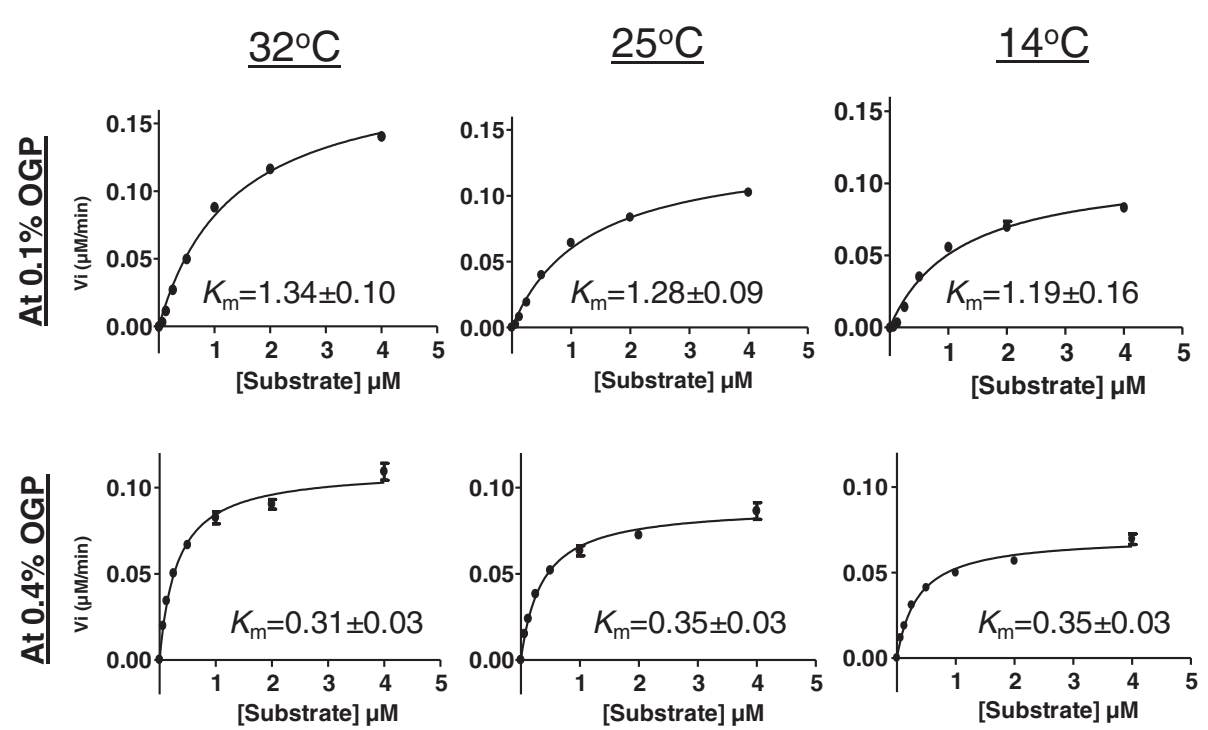

Figure 6 Concentration dependence of Ac-Asp-Glu-Asp(EDANS)-Glu-Glu-Abu- $\psi-[C O O]-A l a-S e r-L y s(D A B C Y L)-N H 2$ [substrate] cleavage by NS3 produced at various temperatures. Substrate-cleavage reactions were performed using 0.1 and $0.4 \%$ OPG as described in Methods. Data points shown were fitted to the Michaelis-Menten equation by non-linear regression.

\section{Structural analysis of NS3 and NS5A-T}

There are no 3 dimensional structures available for HCV NS3 genotype 3a or the full length NS5A of any genotype in protein data bank. Thus, to estimate secondary structure of NS3 and NS5A-T we used data from CD and FT-IR spectroscopy which indicate that both proteins fold into mixed secondary structure components (Figures $5 \mathrm{~A}$ and $\mathrm{B} ; 7 \mathrm{~B}$ and $\mathrm{D}$ ). To provide quantitative estimate of the alpha-helical and beta-sheet content of NS3, the measured amide I region of the spectrum (Figure 7A; Upper panel) could be reproduced by a fit of eight components, dominated by those indicative of alpha-helix and beta-sheet [46-48] (Figure 7B). Quantitative analysis of the spectrum predicted the presence of $25 \%$ alpha-helix and $\sim 34 \%$ beta-sheet structures (Table 3). Similar ratios were obtained from CD data and the homology model of HCV NS3 genotype 3a, built using the $\mathrm{x}$-ray crystal structure of genotype 1a counterpart, as a template (Figure 7C; Table 3) [49,50].
Secondary structures for NS5A, quantified by FT-IR were found to be around $\sim 29 \%$ alpha-helix and beta-sheet each whereas CD analysis revealed $\sim 18 \%$ alpha-helix and $\sim 32 \%$ beta-sheet (Table 3 ). This discrepancy particularly in case of alpha-helix contents might be due to different algorithms used for analysis of CD and FT-IR data.

\section{Conclusions}

We have successfully optimized conditions for the recombinant expression and purification of the NS3 and NS5A proteins from HCV genotype 3a. Yield of the purified NS3 from soluble fraction of $E$. coli cells lysate is $4 \mathrm{mg}$ per liter culture volume, which is the highest amount, obtained for this genotype to the best of our knowledge. CD studies show that difference in activities of NS3 produced at different temperatures is not due to changes in the overall structural features of the expressed proteins. CD and FT-IR spectra suggest that both proteins are folded into a mix of alpha-helix and beta-sheet secondary

Table 2 Catalytic efficiency of NS3 produced at various temperatures

\begin{tabular}{lllll}
\hline Protein & Temperature & $K_{\text {cat }}\left(\mathbf{s}^{-1}\right)$ & $\begin{array}{l}K_{\text {cat }} / K_{\mathrm{m}} \\
\left(\mu \mathrm{M}^{-1} \cdot \mathbf{s}^{-1}\right)\end{array}$ & $\begin{array}{l}K_{\text {cat }} / K_{\mathrm{m}}\left(\mu \mathrm{M}^{-1} \cdot \mathbf{s}^{-1}\right) \\
\times \text { Purification yield }\left(\mathrm{mg} / \mathrm{L}^{1}\right)\end{array}$ \\
\hline NS3 (0.1\% OPG) & $32^{\circ} \mathrm{C}$ & $3.17 \pm 0.10$ & 2.37 & 5.93 \\
& $25^{\circ} \mathrm{C}$ & $2.27 \pm 0.07$ & 1.77 & 7.04 \\
NS3 (0.4\% OPG) & $14^{\circ} \mathrm{C}$ & $1.836 \pm 0.11$ & 1.55 & 6.20 \\
& $32^{\circ} \mathrm{C}$ & $1.840 \pm 0.05$ & 5.93 & 14.82 \\
& $25^{\circ} \mathrm{C}$ & $1.485 \pm 0.04$ & 4.22 & 16.88 \\
\hline
\end{tabular}

${ }^{1}$ The yield of purified proteins were measured milligram per liter of culture (Expression medium). 

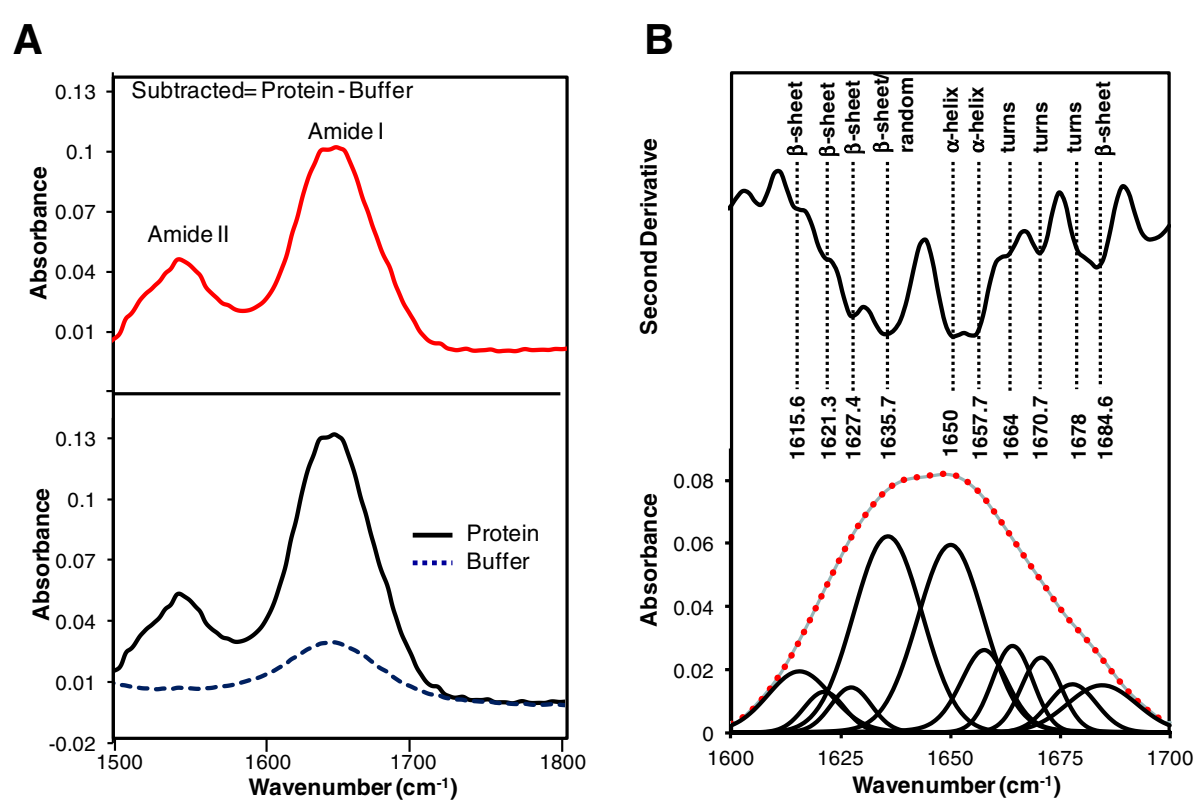

C
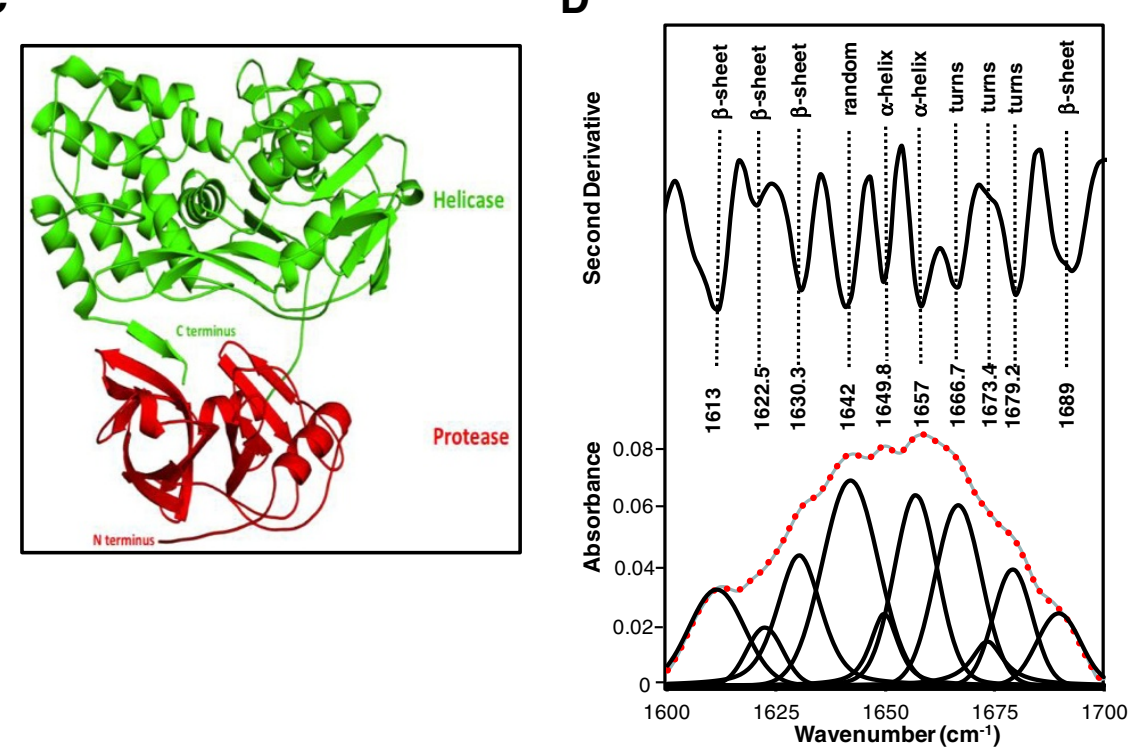

Figure 7 Analysis of $\mathrm{His}_{6}-\mathrm{NS} 3[\mathrm{~A}, \mathrm{~B}, \mathrm{C}]$ and NS5A-T-His 6 [D] secondary structure by FT-IR and homology modeling. [A] Lower panel: FT-IR spectra of hydrated film of $10 \mathrm{mM}$ phosphate buffer pH 7.4 and His - NS3 protein. Upper panel: Final protein spectrum obtained by subtracting the buffer spectrum. [B] Second derivative spectrum of $\mathrm{His}_{6}$-NS3 and amide I region of the FTIR spectrum of a hydrated film of His ${ }_{6}$-NS3 (thick grey line), and bands obtained by deconvolution. The dotted red line shows the curve fitted using the component bands. [C] Homology model of NS3/3a, built using the $x$-ray structure of NS3/1a as a template (PDB id: 308b). The protease and helicase domains are shown in red and green respectively. [D] Second derivative spectrum of NS5A-T-His ${ }_{6}$ and amide I region of the FT-IR spectrum of a hydrated film of NS5A-T-His 6 (thick grey line), and bands obtained by deconvolution. The dotted red line shows the curve fitted using the component bands. The peak position of the spectral components along with their assignment is shown in the figure.

structure. Procedure described here to produce milligram quantities of purified NS3 and NS5A is expected to allow rigorous biochemical and biophysical characterization, and screening of inhibitors to combat HCV infection, in particular of genotype 3 .

\section{Methods}

\section{Extraction of RNA and CDNA synthesis}

Blood samples were collected from different hospitals, already involved in work of HCV diagnostic services (Punjab Institute of Nuclear Medicine, Faisalabad Pakistan and 
Table 3 Secondary structure analysis of $\mathrm{His}_{6}-\mathrm{NS} 3$ and NS5A-T-His 6 by FT-IR, CD spectroscopy and homology modeling

\begin{tabular}{|c|c|c|c|}
\hline Protein & Method & a-helix (\%) & $\beta$-sheet (\%) \\
\hline \multirow[t]{4}{*}{ NS3 } & $\mathrm{FT}^{-\mathrm{R}^{1}}$ & 25.7 & 34.6 \\
\hline & $C D^{2}$ & 24.4 & 46 \\
\hline & $C D^{3}$ & 11 & 37.6 \\
\hline & Homology model ${ }^{4}$ & 25 & 30 \\
\hline \multirow[t]{3}{*}{ NS5A-T } & FT-IR ${ }^{1}$ & 29 & 28 \\
\hline & $C D^{2}$ & 9.1 & 32.7 \\
\hline & $C D^{3}$ & 18 & 37 \\
\hline
\end{tabular}

${ }^{1}$ Bands contributing (FT-IR spectra) to each type of secondary structure are indentified in Figure 7B and 7D respectively. Bands assignments for interpretation of spectra were made on the basis of previous measurements $[48,58] .{ }^{2} \mathrm{CD}$ spectra shown in Figure 5 were analyzed using protein concentration independent method at web based server http://perry.freeshell. org/raussens.html [52]. ${ }^{3} \mathrm{CD}$ spectra were analyzed using DichroWeb server at http://dichroweb.cryst.bbk.ac.uk/html/home.shtml [53,54] and program CONTIN/reference set $3[55] .{ }^{4}$ Secondary structure are estimated from the homology model of NS3/3a, built using the x-ray structure of NS3/1a (PDB ID: 308b) as a template [49].

Liver Center, District Head Quarter Hospital, Faisalabad, Pakistan). Informed consent was taken from every donor and approval of institutional ethical committee was obtained to conduct such studies. Plasma was separated from blood samples by centrifuging them and stored at $-20^{\circ} \mathrm{C}$ until RNA extraction. Total RNA was extracted from these samples infected with HCV genotype 3a using the Viral RNA extraction kit (MACHERYNAGEL, Germany) according to manufacturer's instruction. $140 \mu \mathrm{l}$ of plasma sample was used to extract RNA and finally eluted using the $60 \mu \mathrm{l}$ elution buffer supplied with kit. RNA was quantified using the nanodrop (Thermo Scientific) and stored at $-80^{\circ} \mathrm{C}$ if needed. cDNA was synthesized from the extracted RNA using the primers for NS3 and NS5A (NS3-cDNA and NS5A-cDNA, Table 4) with RevertAid $^{\mathrm{TM}} \mathrm{H}$ Minus First strand cDNA synthesis kit (Fermentas, Germany) according to manufacturer's recommendations.

\section{PCR amplification and construction of expression constructs} Nucleotide sequences of NS3A and NS5A of a number of isolates of HCV genotype 3 a were retrieved from the European Hepatitis C Virus database (http://euhcvdb. ibcp.fr/euHCVdb/) and primers were designed from the consensus sequences of NS3, NS5A and NS5A-T (lacking $\mathrm{N}$-terminal 31 amino acids), using vector NTI software (Invitrogen). Nucleotide coding regions for NS3, NS5A and NS5A-T were amplified from respective cDNA (see section "Extraction of RNA and cDNA synthesis") through gradient polymerase chain reaction (PCR) using NS3-F/R, NS5A-F/R and NS5A-T-F/R, respectively (Table 4) and relevant restriction sites/nucleotides encoding for $6 \times$ His tag were also incorporated. Each reaction mixture of $50 \mu \mathrm{l}$
Table 4 Oligonucleotides used in this study

\begin{tabular}{ll}
\hline Name & Sequence \\
\hline NS3-F & 5'-TATAGGATCCATGCACCATCACCATCATCACGCC \\
& CCGATCACAGCATAC-3' \\
& BamHI \\
NS3-R & 5'-GAGCAAGCTTTTAGGTGGTTACTTCCAGATCAG-3' \\
& Hind III \\
NS5A-F & 5'-GGAATTCCATATGAGCGGTGATTGGCTGCGTA-3' \\
& Ndel \\
NS5A-R & 5'-TCAAAGCTTTIAGTGGTGATGGTGATGATGGCAG \\
& CAGACCACGCTCTGCT-3' \\
& HindIII \\
NS5A-T-F & 5'-GGAATTCCATATGCACCATCACCACCATCACCCTG \\
& GGCTGCCCTTTATTCCT-3' \\
& Ndel \\
NS5A-T-R & 5'-TCAAAGCTTTTAGCAGCAGACCACGCTCTGCT-3' \\
& Hind III \\
NS3-CDNA & 5'-ACCCCTCCAAGCAACACCCA-3' \\
NS5A-CDNA & 5'-ATGTTGCTGCCCATCTCTTG-3' \\
\hline
\end{tabular}

Nucleotides shown as italicized represent the respective restriction sites used for cloning purposes whereas underlined nucleotides sequence encode for oligohistidine tag, incorporated into genes of interest for downstream purification processes.

contains $5 \mu \mathrm{l}$ of cDNA, $0.2 \mathrm{mM}$ dNTPs, $2 \mathrm{mM} \mathrm{MgSO}_{4}$, $0.5 \mu \mathrm{M}$ of each forward and reverse primer, $1.25 \mathrm{U}$ of Pfu DNA Polymerase and 1X Pfu buffer (200 mM Tris$\mathrm{HCl} \mathrm{pH} \mathrm{8.8,} 100 \mathrm{mM}\left(\mathrm{NH}_{4}\right)_{2} \mathrm{SO}_{4}, 100 \mathrm{mM} \mathrm{KCl}, 1 \%$ Triton $\mathrm{X}-100,1 \mathrm{mg} / \mathrm{mL}$ BSA (Fermentas, Germany).

The procedures for cloning were based on standard methods [51] and protocols recommended by the suppliers. Purified PCR products corresponding to NS3, NS5A and NS5A-T were restricted using the restriction enzymes BamHI/HindIII, NdeI/HindIII and NdeI/HindIII, respectively and ligated into pET11a vector that was restricted using same restriction enzymes. The resulting constructs were named as pET11a-His ${ }_{6}-\mathrm{NS} 3$, pET11a-NS5A-His 6 and pET11a-NS5A-T-His 6 . The identity of plasmids was confirmed by nucleotide sequencing. All genetic manipulation was performed in Escherichia coli strain XL1Blue (Stratagene, USA). Nucleotide sequences of NS3 and NS5A were deposited in GenBank NCBI under accession numbers JQ676838 and JQ676840, respectively.

\section{Expression of NS3, NS5A and NS5A-T in E. coli}

For initial expression trials, pET11a-His ${ }_{6}-\mathrm{NS} 3$, pET11a$\mathrm{NS}_{5 \mathrm{~A}-\mathrm{His}_{6} \text { and pET11a-NS5A-T-His }}$ were transformed into the $E$. coli strain BL21(DE3) cells and were grown at $37^{\circ} \mathrm{C}$ in a $50 \mathrm{~mL}$ of $\mathrm{LB}$ media supplemented with $100 \mu \mathrm{g} / \mathrm{mL}$ of ampicillin until $\mathrm{OD}_{600}$ reaches 0.5-0.6. The cells were then induced with $1 \mathrm{mM}$ isopropyl $\beta$ D-1-thiogalactopyranoside (IPTG) and were grown for additional three hours. E. coli cells expressing $\mathrm{His}_{6}-\mathrm{NS} 3$, 
NS5A-His 6 and $\mathrm{His}_{6}-\mathrm{NS} 5 \mathrm{~A}-\mathrm{T}$ were harvested by centrifugation at $5000 \mathrm{rpm}$ using the Beckman centrifuge and resuspended in lysis buffers, 25 mM HEPES [4-(2hydroxyethyl)-1-piperazineethanesulfonic Acid] pH 7.6 containing $20 \%$ glycerol, $0.5 \mathrm{M} \mathrm{NaCl}, 2.5 \mathrm{mM} \beta$ mercaptoethanol, $0.2 \% \mathrm{n}$-dodecyl- $\beta$-D-maltopyranoside and $100 \mathrm{mM}$ Tris- $\mathrm{HCl} \mathrm{pH} 8.0$ containing $0.5 \%$ triton; $200 \mathrm{mM} \mathrm{NaCl} ; 10 \mathrm{mM} \beta$-Mercaptoethanol and 10\% glycerol, respectively. Before sonication, in case of NS5A cell resuspensions were supplemented with few $\mu \mathrm{g}$ of DNase, RNase and 1-tablet of EDTA-free protease cocktail inhibitor (Roche, Germany). Following disruption of cells by sonication, soluble fraction was separated from insoluble portion by spinning at $12000 \times g$ for $30 \mathrm{~min}$. The pellet representing the insoluble fraction was dissolved in respective lysis buffer and equal volume of both soluble and insoluble fractions were analyzed on SDS-polyacrylamide gel.

To optimize the inducer concentration for expression of $\mathrm{His}_{6}$-NS3 and $\mathrm{His}_{6}-\mathrm{NS} 5 \mathrm{~A}-\mathrm{T}$, various quantities of IPTG $0.1 \mathrm{mM}, 0.25 \mathrm{mM}, 0.5 \mathrm{mM}, 0.75 \mathrm{mM}$ and $1 \mathrm{mM}$ IPTG were used in expression experiments and analyses were performed as described before. To enhance solubility and yield of $\mathrm{His}_{6}-\mathrm{NS} 3$ and $\mathrm{His}_{6}-\mathrm{NS} 5 \mathrm{~A}-\mathrm{T}$, following induction of cultures using $1 \mathrm{mM}$ and $0.5 \mathrm{mM}$ IPTG respectively, optimization of temperature was carried out at $32^{\circ} \mathrm{C}, 25^{\circ} \mathrm{C}$ and $14^{\circ} \mathrm{C}$. For $32^{\circ} \mathrm{C}, 25^{\circ} \mathrm{C}$ and $14^{\circ} \mathrm{C}$ post-induction time was kept 4 and 12 hours respectively. Expressed proteins were analyzed by SDS-PAGE.

\section{Purification of NS3}

To estimate yield of purified $\mathrm{His}_{6}-\mathrm{NS} 3$ at various postinduction temperatures $32^{\circ} \mathrm{C}, 25^{\circ} \mathrm{C}$ and $14^{\circ} \mathrm{C}, 1.5 \mathrm{~L}$ expression culture was set up at each temperature. Before IPTG induction, culture media was supplemented with $100 \mu \mathrm{M}$ of $\mathrm{ZnCl}_{2}$.

For purification, the ÄKTA explorer platform (GE Healthcare) was used. All purification procedures were performed at $4^{\circ} \mathrm{C}$. The pellet was resuspended in $25 \mathrm{~mL}$ lysis buffer (25 mM HEPES [4-(2-hydroxyethyl)-1-piperazineethanesulfonic Acid] $\mathrm{pH} 7.6$ containing $20 \%$ glycerol, $0.5 \mathrm{M} \mathrm{NaCl}, 2.5 \mathrm{mM} \beta$-mercaptoethanol, $0.2 \%$ $\mathrm{n}$-dodecyl- $\beta$-D-maltopyranoside. The cells were lysed using cell disrupter at $17 \mathrm{Kpsi}$ (Constant Systmes, Ltd) and lysate was centrifuged for $50 \mathrm{~min}$ at $12000 \times g$. The pellet was discarded and supernatant was loaded on the chelating sepharose FastFlow gel charged with Nickel (GE healthcare) pre-equilibrated with lysis buffer. To remove non-specific loosely bound protein from Nickel-sepharose matrix, a step gradient with increasing concentration of imidazole ( $5 \mathrm{mM}$ and $50 \mathrm{mM}$ ) in lysis buffer was used. $\mathrm{His}_{6}$-NS3 was then eluted using the lysis buffer except containing $250 \mathrm{mM}$ imidazole.
The peak protein fractions were pooled and applied on PD-10 desalting columns (GE Healthcare) pre-equilibrated with buffer (25 mM HEPES pH 7.6 containing 20\% glycerol, $0.2 \mathrm{M} \mathrm{NaCl}, 10 \mathrm{mM} \beta$-mercaptoethanol, $0.1 \%$ $\mathrm{n}$-dodecyl- $\beta$-D-maltopyranoside) to remove the excess of imidazole. Concentration of purified $\mathrm{His}_{6}$-NS3 was measured using nanodrop and Pierce ${ }^{\mathrm{Tm}} 660 \mathrm{~nm}$ protein assay (Thermo Scientific). The purified protein was stored at $-80^{\circ} \mathrm{C}$ in small portions. Purity of the purified protein was judged by SDS-PAGE.

\section{Purification of NS5A-T}

For purification of $\mathrm{His}_{6}-\mathrm{NS} 5 \mathrm{~A}-\mathrm{T}$, cultures were grown exactly as explained for $\mathrm{His}_{6}$-NS3 except protein expression was induced using $0.5 \mathrm{mM}$ IPTG. Cells containing over-expressed $\mathrm{His}_{6}$-NS5A-T were lysed and processed as described before for $\mathrm{His}_{6}-\mathrm{NS} 3$. Soluble fraction from lysate was loaded on sepharose-Nickel column pre-equilibrated with lysis buffer $(100 \mathrm{mM}$ Tris- $\mathrm{HCl}$ pH 8.0 containing $0.1 \%$ triton, $200 \mathrm{mM} \mathrm{NaCl}, 10 \mathrm{mM} \beta$-Mercaptoethanol and $10 \%$ glycerol). The column was washed with 10 and 3 column volume lysis buffer containing 10 and $60 \mathrm{mM}$ imidazole, respectively. The protein was eluted using lysis buffer containing $300 \mathrm{mM}$ imidazole. Peak fractions were pooled and concentrated using $30 \mathrm{kDa}$ cutoff Vivaspin column (Sartorius, Germany). The concentrated protein sample was then loaded onto superdex 200 gel filtration column pre-equilibrated with the buffer (25 mM HEPES $\mathrm{pH} 7.5$ containing $150 \mathrm{mM} \mathrm{NaCl}, 2 \mathrm{mM}$ DTT and $10 \%$ glycerol) and let the sample pass through the column with a flow rate of $0.5 \mathrm{~mL} / \mathrm{min}$. The fractions with high UV absorption were collected and analyzed by SDS-PAGE.

\section{Circular dichroism spectroscopy analysis of NS3 and NS5A-T}

Structural analysis of $\mathrm{His}_{6}-\mathrm{NS} 3$ produced at $32^{\circ} \mathrm{C}, 25^{\circ} \mathrm{C}$ and $14^{\circ} \mathrm{C}$ were performed using CD spectroscopy. Measurements were carried out using J-810, Jascon spectroplolarimeter at $25^{\circ} \mathrm{C}$ with constant nitrogen flushing. Samples $(300 \mu \mathrm{l})$ containing the purified $\mathrm{His}_{6}-\mathrm{NS} 3$ and His $_{6}-\mathrm{NS} 5 \mathrm{~A}-\mathrm{T}$ at a concentration of $0.02 \mathrm{mg} / \mathrm{mL}$ (in $10 \mathrm{mM}$ potassium phosphate $\mathrm{pH} 7.4$ buffer supplemented with $20 \%$ glycerol, $0.1 \%$ n-octyl- $\beta$-D-glycopyranosid) and $0.05 \mathrm{mg} / \mathrm{mL}$ (in $10 \mathrm{mM}$ potassium phosphate $\mathrm{pH} 7.4$ buffer) respectively, were added into a Hellma quartz cuvette of $1 \mathrm{~mm}$ path length and scanned between 185 and $260 \mathrm{~nm}$, averaging at least 10 accumulations. Similarly, blank samples containing $10 \mathrm{mM}$ phosphate buffer $\mathrm{pH} 7.4$ supplemented with $20 \%$ glycerol, $0.1 \%$ n-octyl- $\beta$-D-glycopyranosid or $10 \mathrm{mM}$ phosphate buffer $\mathrm{pH} 7.4$ were scanned. Spectra were recorded at a speed of $1 \mathrm{~nm} / 15 \mathrm{sec}$, sensitivity 50 mdeg, bandwidth $0.5 \mathrm{~nm}$, resolution $1 \mathrm{~nm}$ and response time $15 \mathrm{sec}$. 
CD data were analyzed using protein concentration independent method at web based server http://perry. freeshell.org/raussens.html [52] and DichroWeb server at http://dichroweb.cryst.bbk.ac.uk/html/home.shtml $[53,54]$ and program CONTIN/reference set 3 [55].

\section{Activity measurements of NS3}

The protease activity was measured with fluorescence resonance energy transfer assay (FRET) using the depsipeptide substrate Ac-Asp-Glu-Asp(EDANS)-Glu-GluAbu- $\psi-[C O O]-A l a-S e r-L y s(D A B C Y L)-N H 2$ (AnaSpec, San Jose, CA, USA). NS3 Protease cleave this substrate resulting in production of fluorescence which can be measured continuously on a fluorescence plate reader (Fluoroskan, Ascent Labsystems, Sweden) with excitation and emission wavelengths at 355 and $510 \mathrm{~nm}$, respectively. The cofactor for NS3 protease activity is a synthetic peptide "KKGSVVIVGRIVLSGK" which is the central part of HCV NS4A. For activity measurement, purified $\mathrm{His}_{6}$-NS3 was diluted to $1 \mathrm{nM}$ with the assay buffer (50 mM HEPES pH 7.5 containing $10 \mathrm{mM} \mathrm{DTT,} \mathrm{40 \%}$ glycerol and 0.1 or $0.4 \%$ n-octyl- $\beta$-D-glycopyranoside), pre-incubated for $10 \mathrm{~min}$ at $30^{\circ} \mathrm{C}$ with $25 \mu \mathrm{M}$ NS4Apeptide (dissolved in dimethyl sulfoxide). The assay buffer with 0.1 or $0.4 \%$ OPG was used in order to see the effect of detergent concentration on activity of NS3. The reaction was started by adding $10 \mu \mathrm{l}$ of depsipeptide substrate in 2 fold dilution with highest concentration of $4 \mu \mathrm{M}$ in a microtitre plate. The last well in microtitre plate was used as control containing no substrate in it. Corrections for inner filter effect of substrate were also performed [56]. Kinetic properties of enzyme $\left(K_{\mathrm{m}}, K_{\mathrm{cat}}\right.$ and $\left.K_{\text {cat }} / K_{\mathrm{m}}\right)$ were measured by fitting the Michaelis-Menten equation by non-linear regression using the GraFit software (Erithacus Software, Staines, MX, UK).

\section{FT-IR analysis of NS3 and NS5A-T}

For infrared spectroscopy, purified $\mathrm{His}_{6}-\mathrm{NS} 3$ and $\mathrm{His}_{6}$ NS5A-T in $10 \mathrm{mM}$ potassium phosphate buffer $\mathrm{pH} 7.4$ supplemented with $0.1 \%$ n-dodecyl- $\beta$-D-maltopyranoside and $10 \mathrm{mM}$ potassium phosphate buffer $\mathrm{pH} 7.4$, respectively, were concentrated to $\sim 5-6 \mathrm{mg} / \mathrm{mL}$. A small amount $(\sim 15 \mu \mathrm{l})$ of sample was dried on platinum ATR platform (diamond crystal) to form a hydrated film and then spectra obtained using Bruker FT-IR spectrometer as described [57]. Briefly FT-IR spectra from 4000 to $500 \mathrm{~cm}^{-1}$ were collected in absorbance mode at $1 \mathrm{~nm}$ resolution, 256 scans coaddition and Blackman-Harris-3-term apodization. Similarly, spectra was recorded for buffer alone and subtracted from protein spectra to eliminate bending vibration of $\mathrm{H}_{2} \mathrm{O}$ that gives absorption band at around $1645 \mathrm{~cm}^{-1}$ in the amide I region. Subtracted protein spectra were manipulated by adjusting the subtraction factor until a flat baseline was obtained in the region between $2000-1770 \mathrm{~cm}^{-1}$. Where necessary, subtraction of residual vapour absorption was also performed.

For secondary structure analysis, second derivative of spectra corresponding to amide I region (1700-1600 $\mathrm{cm}^{-1}$ ) was obtained using the Origin software version 7.0 (OriginLab Corporation, USA) following Savitzky-Golay method using the parameters $3^{\text {rd }}$ grade polynomial, point to left/right : 2 and five smoothing points. Before performing second derivative analyses, spectra were smoothened using 2 adjacent points. Decomposition of the spectra into individual bands in the amide I region was performed by non-linear peak fitting using Galactic PeakSolve ${ }^{\mathrm{TM}}$ software (version 1.05). Band assignments for interpretation of spectra were done on the basis of previous measurements $[48,58]$.

\section{Homology modeling}

The 3D structure of HCV-3a NS3 protein was predicted through homology modeling, using the SWISS-MODEL Workspace [50,59]. 629 amino acids (3-631) were modeled using the $\mathrm{x}$-ray structure of $\mathrm{HCV}-1 \mathrm{a}$ NS3 protein as a template (PDB ID: 3o8b, sequence identity $83 \%$ ). The homology model was further idealized using the CCP4 program suite $[60,61]$. The final model was validated using the NIH MBI Laboratory for Structural Genomics and Proteomics Structural Analysis and Verification Server that allow use of five programs (Procheck, What_Check, ERRAT,Verify_3D, and Prove) to analyze the stereochemical parameters and quality of the model [62-66].

Competing interests

The authors declare that they have no competing interests.

\section{Authors' contributions}

MIA performed cloning, expression, purification and kinetic work, and assisted in writing the manuscript. MI performed CD and IR analysis, and drafted the manuscript. MSY built the homology model and helped in drafting of the manuscript. MR conceived the idea of study, designed, coordinated the research and written the manuscript. All authors read and approved the final manuscript.

\section{Acknowledgements}

We are grateful to Higher Education Commission, Pakistan, for the PhD studentship award to MIA and to U. Helena Danielson, Uppsala University, Sweden for training to MIA for conducting kinetic studies under International Research Support Initiative Program of HEC.

\section{Author details}

${ }^{1}$ Drug Discovery and Structural Biology group, Health Biotechnology Division, National Institute for Biotechnology and Genetic Engineering (NIBGE), Faisalabad, Pakistan. ${ }^{2}$ Department of Physics, College of Arts and Sciences, Southern Illinois University, Edwardsville, Edwardsville, IL 62026-1654, USA. ${ }^{3}$ Biophysics Department, Faculty of Science, Cairo University, Giza 12613, Egypt.

Received: 24 July 2013 Accepted: 12 November 2013 Published: 16 November 2013

\section{References}

1. Kubo Y, Takeuchi K, Boonmar S, Katayama T, Choo QL, Kuo G, Weiner AJ, Bradley DW, Houghton M, Saito I, et al: A cDNA fragment of hepatitis C virus isolated from an implicated donor of post-transfusion non- $A$, non- $B$ hepatitis in Japan. Nucleic Acids Res 1989, 17:10367-10372. 
2. Tan SL (Ed): Hepatitis C Viruses: Genomes and Molecular Biology. Norfolk UK: Horizon Bioscience; 2006.

3. Chisari FV: Unscrambling hepatitis C virus-host interactions. Nature 2005, 436:930-932.

4. Timpe JM, McKeating JA: Hepatitis C virus entry: possible targets for therapy. Gut 2008, 57:1728-1737.

5. Ishii K, Tanaka Y, Yap C-C, Aizaki H, Matsuura Y, Miyamura T: Expression of hepatitis C virus NS5B protein: Characterization of its RNA polymerase activity and RNA binding. Hepatology 1999, 29:1227-1235.

6. Suzuki T, Ishii K, Aizaki H, Wakita T: Hepatitis C viral life cycle. Adv Drug Deliv Rev 2007, 59:1200-1212

7. Chayama K, Hayes CN: Hepatitis C virus: how genetic variability affects pathobiology of disease. J Gastroenterol Hepatol 2011, 26(Suppl 1):83-95.

8. Rehermann $B$ : Hepatitis $C$ virus versus innate and adaptive immune responses: a tale of coevolution and coexistence. J Clin Invest 2009, 119:1745-1754.

9. Moradpour D, Penin F, Rice CM: Replication of hepatitis C virus. Nat Rev Microbiol 2007, 5:453-463.

10. Feld JJ, Hoofnagle $\mathrm{JH}$ : Mechanism of action of interferon and ribavirin in treatment of hepatitis C. Nature 2005, 436:967-972.

11. Schlutter J: Therapeutics: new drugs hit the target. Nature 2011, 474:S5-S7.

12. Rehman S, Ashfaq U, Javed T: Antiviral drugs against Hepatitis C Virus. Genet Vaccin Ther 2011, 9:11.

13. Kiser JJ, Flexner C: Direct-acting antiviral agents for Hepatitis $C$ virus infection. Annu Rev Pharmacol Toxicol 2013, 53:427-449.

14. Mullard A: FDA drug approvals. Nat Rev Drug Discov 2011, 2012(11):91-94

15. Kwo $P Y$, Vinayek $R$ : The therapeutic approaches for hepatitis $C$ virus: protease inhibitors and polymerase inhibitors. Gut Liver 2011, 5:406-417.

16. Morikawa K, Lange CM, Gouttenoire J, Meylan E, Brass V, Penin F, Moradpour D: Nonstructural protein 3-4A: the Swiss army knife of hepatitis C virus. J Viral Hepat 2011, 18:305-315.

17. Chatel-Chaix L, Baril M, Lamarre D: Hepatitis C Virus NS3/4A Protease Inhibitors: A Light at the End of the Tunnel. Viruses 2010, 2:1752-1765.

18. Locatelli GA, Gosselin G, Spadari S, Maga G: Hepatitis C virus NS3 NTPase/ Helicase: different stereoselectivity in nucleoside triphosphate utilisation suggests that NTPase and helicase activities are coupled by a nucleotide-dependent rate limiting step. J Mol Biol 2001, 313:683-694.

19. Raney KD, Sharma SD, Moustafa IM, Cameron CE: Hepatitis C virus non-structural protein 3 (HCV NS3): a multifunctional antiviral target. J Biol Chem 2010, 285:22725-22731.

20. Macdonald A, Harris M: Hepatitis C virus NS5A: tales of a promiscuous protein. J Gen Virol 2004, 85:2485-2502.

21. Foster TL, Belyaeva T, Stonehouse NJ, Pearson AR, Harris M: All three domains of the Hepatitis C virus nonstructural NS5A protein contribute to RNA binding. J Virol 2010, 84:9267-9277.

22. Kim K, Hwan K, Ha E, Young J, Sakamoto N, Cheong J: Hepatitis C virus NS5A protein increases hepatic lipid accumulation via induction of activation and expression of PPARgamma. FEBS Lett 2009, 583:2720-2726.

23. Targett-adams P, Boulant S, Douglas MW, Mclauchlan J: Lipid Metabolism and HCV Infection; 2010:1195-1217.

24. Gao M, Nettles RE, Belema M, Snyder LB, Nguyen VN, Fridell RA, Serrano-Wu MH, Langley DR, Sun JH, O'Boyle DR 2nd, et al: Chemical genetics strategy identifies an HCV NS5A inhibitor with a potent clinical effect. Nature 2010, 465:96-100.

25. Tellinghuisen $T L$, Foss $K L$, Treadaway J: Regulation of Hepatitis C virion production via phosphorylation of the NS5A protein. PLOS Pathog 2008, 4(3):e1000032. doi:10.1371/journal.ppat.1000032.

26. Tellinghuisen TL, Foss KL, Treadaway JC, Rice CM: Identification of residues required for RNA replication in domains II and III of the hepatitis C virus NS5A protein. J Virol 2008, 82:1073-1083.

27. Love RA, Brodsky O, Hickey MJ, Wells PA, Cronin CN: Crystal structure of a novel dimeric form of NS5A domain I protein from hepatitis $C$ virus. J Virol 2009, 83:4395-4403.

28. Waheed Y, Shafi T, Safi SZ, Qadri I: Hepatitis C virus in Pakistan: a systematic review of prevalence, genotypes and risk factors. World J Gastroenterol 2009, 15:5647-5653.

29. Idrees M, Rafique S, Rehman I, Akbar H, Yousaf MZ, Butt S, Awan Z, Manzoor S, Akram M, Aftab M, et al: Hepatitis C virus genotype 3a infection and hepatocellular carcinoma: Pakistan experience. World J Gastroenterol 2009, 15:5080-5085.

30. Summa V, Ludmerer SW, McCauley JA, Fandozzi C, Burlein C, Claudio G, Coleman PJ, Dimuzio JM, Ferrara M, Di Filippo M, et al: MK-5172, a selective inhibitor of Hepatitis C virus NS3/4a protease with broad activity across genotypes and resistant variants. Antimicrob Agents Chemother 2012, 56:4161-4167

31. Chayama K, Takahashi S, Toyota J, Karino Y, Ikeda K, Ishikawa H, Watanabe $H$, McPhee F, Hughes E, Kumada $H$ : Dual therapy with the nonstructural protein $5 \mathrm{~A}$ inhibitor, daclatasvir, and the nonstructural protein 3 protease inhibitor, asunaprevir, in hepatitis $C$ virus genotype $1 \mathrm{~b}$-infected null responders. Hepatology 2012, 55:742-748.

32. Pol S: Oral antiviral therapies for chronic hepatitis $C$ infection. Ther Adv Infect Dis 2013, 1:107-116.

33. Suk-Fong Lok A: HCV NS5A inhibitors in development. Clin Liver Dis 2013, 17:111-121

34. Rimmert B, Sabet S, Ackad E, Yousef MS: A 3D structural model and dynamics of hepatitis $C$ virus NS3/4A protease (genotype $4 a$, strain ED43) suggest conformational instability of the catalytic triad: implications in catalysis and drug resistivity. J Biomo/ Struct Dyn 2013, doi: 10.1080/07391102.2013.800001.

35. Penin F, Brass V, Appel N, Ramboarina S, Montserret R, Ficheux D, Blum HE, Bartenschlager R, Moradpour D: Structure and function of the membrane anchor domain of hepatitis $C$ virus nonstructural protein 5A. J Biol Chem 2004, 279:40835-40843.

36. Moradpour D, Brass V, Penin F: Function follows form: the structure of the N-terminal domain of HCV NS5A. Hepatology 2005, 42:732-735.

37. Sadeghi HM, Rabbani M, Rismani E, Moazen F, Khodabakhsh F, Dormiani K, Khazaei Y: Optimization of the expression of reteplase in Escherichia coli. Res Pharm Sci 2011, 6:87-92.

38. Poliakov A, Hubatsch I, Shuman CF, Stenberg G, Danielson UH: Expression and purification of recombinant full-length NS3 protease-helicase from a new variant of Hepatitis C virus. Protein Expr Purif 2002, 25:363-371.

39. Thibeault D, Bousquet C, Gingras R, Lagacé L, Maurice R, White PW, Lamarre D: Sensitivity of NS3 serine proteases from hepatitis C virus genotypes 2 and 3 to the inhibitor BILN 2061. J Virol 2004, 78:7352-7359.

40. Fatima K, Tahir M, Qadri I: Development of robust in vitro serine protease assay based on recombinant Pakistani HCV NS3-4A protease. Virus Res 2011, 160:230-237

41. Huang L, Sineva EV, Hargittai MRS, Sharma SD, Suthar M, Raney KD, Cameron CE: Purification and characterization of hepatitis $C$ virus non-structural protein 5A expressed in Escherichia coli. Protein Expr Purif 2004, 37:144-153.

42. Ivanov AV, Korovina AN, Tunitskaya VL, Kostyuk DA, Rechinsky VO, Kukhanova MK, Kochetkov SN: Development of the system ensuring a high-level expression of hepatitis C virus nonstructural NS5B and NS5A proteins. Protein Expr Purif 2006, 48:14-23.

43. Shelton $\mathrm{H}$, Harris M: Hepatitis C virus NS5A protein binds the SH3 domain of the Fyn tyrosine kinase with high affinity: mutagenic analysis of residues within the $\mathrm{SH} 3$ domain that contribute to the interaction. Virol J 2008, 5:24.

44. Huang L, Hwang J, Sharma SD, Hargittai MRS, Chen Y, Arnold JJ, Raney KD, Cameron CE: Hepatitis C virus nonstructural protein $5 \mathrm{~A}$ (NS5A) is an RNA-binding protein. J Biol Chem 2005, 280:36417-36428.

45. Kelly SM, Jess TJ, Price NC: How to study proteins by circular dichroism. Biochim Biophys Acta 2005, 1751:119-139.

46. Arrondo JL, Muga A, Castresana J, Goni FM: Quantitative studies of the structure of proteins in solution by Fourier-transform infrared spectroscopy. Prog Biophys Mol Biol 1993, 59:23-56.

47. Goormaghtigh E, Cabiaux V, Ruysschaert JM: Determination of soluble and membrane protein structure by Fourier transform infrared spectroscopy III. Secondary structures. Subcell Biochem 1994, 23:405-450.

48. Goormaghtigh $E_{,}$Cabiaux V, Ruysschaert JM: Determination of soluble and membrane protein structure by Fourier transform infrared spectroscopy. I. Assignments and model compounds. Subcell Biochem 1994, 23:329-362.

49. Appleby TC, Anderson R, Fedorova O, Pyle AM, Wang R, Liu X, Brendza KM, Somoza JR: Visualizing ATP-dependent RNA translocation by the NS3 helicase from HCV. J Mol Biol 2011, 405:1139-1153.

50. Bordoli L, Kiefer F, Arnold K, Benkert P, Battey J, Schwede T: Protein structure homology modeling using SWISS-MODEL workspace. Nat Protocols 2008, 4:1-13.

51. Sambrook J: Molecular cloning: a laboratory Manual/Joseph Sambrook. Edited by Russell DW. Cold Spring Harbor, N.Y: Cold Spring Harbor Laboratory; 2001

52. Raussens V, Ruysschaert J-M, Goormaghtigh E: Protein concentration is not an absolute prerequisite for the determination of secondary structure 
from circular dichroism spectra: a new scaling method. Anal Biochem 2003, 319:114-121.

53. Whitmore L, Wallace B: DICHROWEB, an online server for protein secondary structure analyses from circular dichroism spectroscopic data. Nucleic Acids Res 2004, 32:W668-W673.

54. Whitmore L, Wallace BA: Protein secondary structure analyses from circular dichroism spectroscopy: methods and reference databases. Biopolymers 2008, 89:392-400.

55. Provencher SW, Gloeckner J: Estimation of globular protein secondary structure from circular dichroism. Biochemistry 1981, 20:33-37.

56. Liu Y, Kati W, Chen C-M, Tripathi R, Molla A, Kohlbrenner W: Use of a fluorescence plate reader for measuring kinetic parameters with inner filter effect correction. Anal Biochem 1999, 267:331-335.

57. Iram N, Shah MS, Ismat F, Habib M, Iqbal M, Hasnain SS, Rahman M: Heterologous expression, characterization and evaluation of the matrix protein from Newcastle disease virus as a target for antiviral therapies. Appl Microbiol Biotechnol 2013. doi:10.1007/s00253-013-5043-2.

58. Susi $\mathrm{H}$, Byler DM: Resolution-enhanced fourier transform infrared spectroscopy of enzymes. Methods Enzymol 1986, 130:290-311.

59. Arnold K, Bordoli L, Kopp J, Schwede T: The SWISS-MODEL workspace: a web-based environment for protein structure homology modelling. Bioinformatics 2006, 22:195-201.

60. Potterton E, Briggs $P$, Turkenburg M, Dodson E: A graphical user interface to the CCP4 program suite. Acta Crystallogr D Biol Crystallogr 2003, 59:1131-1137

61. Winn MD, Ballard CC, Cowtan KD, Dodson EJ, Emsley P, Evans PR, Keegan RM Krissinel EB, Leslie AG, McCoy A: Overview of the CCP4 suite and current developments. Acta Crystallogr D Biol Crystallogr 2011, 67:235-242.

62. Colovos C, Yeates TO: Verification of protein structures: patterns of nonbonded atomic interactions. Protein Sci 1993, 2:1511-1519.

63. Hooft R, Vriend G, Sander C, Abola EE: Errors in protein structures. Nature 1996, 381:272.

64. Laskowski RA, MacArthur MW, Moss DS, Thornton JM: PROCHECK: a program to check the stereochemical quality of protein structures. J App/ Crystallogr 1993, 26:283-291.

65. Liithy R, Bowie JU, Eisenberg D: Assessment of protein models with three-dimensional profiles. Nature 1992, 356:83-85.

66. Pontius J, Richelle J, Wodak SJ: Deviations from standard atomic volumes as a quality measure for protein crystal structures. J Mol Biol 1996 264:121-136.

doi:10.1186/1475-2859-12-111

Cite this article as: Anwar et al.: Over-expression and characterization of NS3 and NS5A of Hepatitis C virus genotype 3a. Microbial Cell Factories 2013 12:111.

\section{Submit your next manuscript to BioMed Central and take full advantage of:}

- Convenient online submission

- Thorough peer review

- No space constraints or color figure charges

- Immediate publication on acceptance

- Inclusion in PubMed, CAS, Scopus and Google Scholar

- Research which is freely available for redistribution 